\title{
National Culture and the Gender Diversity of Corporate Boards
}

\author{
Catherine Whelan \\ The University of Notre Dame Australia \\ Sarah A. Humphries \\ Georgia College \& State University
}

Controlling for board size and the presence of a female chairperson, this study investigates the association between the gender diversity of corporate boards and the six Hofstede cultural dimensions. Results indicate that the percentage of women on boards is negatively related to Power Distance and positively related to Individualism and Long-term Orientation. The percentage of women on boards tends to be higher in cultures that tolerate inequalities in the distribution of power. There is also evidence that the percentage of women on boards is influenced by the degree of interdependence a society maintains among its members and the long-term horizon of decision making.

Keywords: national culture, gender diversity, corporate governance

\section{INTRODUCTION}

Gender diversity on corporate boards has been a topic of discussion for several years with the general consensus being that greater diversity enhances the effectiveness of the board. Some jurisdictions, particularly in Europe, have begun to impose legislated quotas for female representation on corporate boards. Other countries promote self-regulation with the goal of voluntarily increasing gender diversity on boards. Over the next decade, a decline in the differences among countries may occur as more regulatory bodies impose gender diversity requirements through corporate governance codes. Identifying the factors that influence acceptance of diversity on boards would be of interest to those attempting change.

Extensive literature exists that investigates gender diversity of boards and the relationship to firm performance (Carter et al., 2003; Erhardt et al., 2003). Furthermore, there is a demonstrated link between the characteristics of corporate boards and national culture (Li \& Harrison, 2008; Terjesen \& Singh, 2008; Carrasco et al., 2015). This study investigates the impact of national culture on the gender diversity of corporate boards by examining the proportion of female board members for multinational companies that are listed only on the New York Stock Exchange or the London Stock Exchange. As these exchanges do not currently impose gender diversity requirements for listed companies, it is assumed that the board diversity of the companies in the sample is influenced by the country of operation rather than regulatory requirements in the country of listing. The national culture dimensions are drawn from Hofstede et al. (2010), with the inclusion of Long-term Orientation and Indulgence being unique to this study.

Results indicate a significant relationship between national culture and the gender diversity of corporate boards. There is evidence to support the hypotheses that the percentage of women on boards is 
higher in countries with higher scores on the Individualism and Long-term Orientation dimensions and lower scores on the Power Distance dimension.

The remainder of the paper is structured as follows. A literature review and hypotheses development are presented in the next section followed by the methodology, discussion of results, and conclusions.

\section{LITERATURE REVIEW}

\section{Gender Diversity and Firm Performance}

The board of directors is seen as a monitoring mechanism aimed at reducing agency costs that arise from the misalignment of objectives between management and shareholders (Jensen 1993). It has been suggested that creativity and quality of decision making is enhanced with greater board diversity due to the consideration of different perspectives. Characteristics of the board, as influencers of firm performance, have been an area of interest for some time. In particular, prior studies have found an association between firm performance and board diversity, in terms of both gender and ethnicity (Carter et al., 2003; Erhardt et al., 2003). Carter et al. (2003) also found that gender diversity tended to increase with firm size and board size.

More recently, research in this area has focused specifically on gender diversity of corporate boards. In the US, a female is more likely to be appointed to a board when the outgoing board member was a female (Tinsley et al., 2017). Similar results were found for male board members although the effect is smaller than that for female directors. It was also found that the likelihood of selecting a female replacement was significantly increased when the available number of female candidates for the position was higher.

There have also been numerous studies examining the link between board diversity and firm performance. These studies have generated mixed results; however, most findings indicate a positive relationship between gender diversity of the board and firm performance using data from a broad range of countries (Low et al., 2015; Sabatier, 2015; Geiger \& Marlin, 2016; Sanan, 2016; Solakoglu \& Demir, 2016; Terjesen et al., 2016, Tinsley et al., 2017). One explanation for the conflicting results in corporate governance research mentioned above is the endogeneity of the variables. For example, while firm performance may be influenced by the composition of the existing board of directors, past performance may have led to a change to the structure of the board to its current composition. An interesting discussion of this issue in can be found in Hermalin and Weisbach (2001).

Solakoglu and Demir (2016) evaluated how the relationship between gender diversity and firm performance is influenced by firm-specific factors through examination of firms listed on the Borsa Instanbul. Overall, they found some support for the impact of gender diversity on firm performance. However, this relationship was stronger for firms targeting local markets, firms in the financial sector, and firms that were family or block-owned. In a multi-country study undertaken by Terjesen et al. (2016) using almost 4,000 public companies from 47 countries, firm performance was investigated using both market and accounting measures. Gender diversity was shown to improve firm performance and also to enhance the effectiveness of external independent directors.

This body of research provides evidence that gender diversity of corporate boards is associated with higher firm performance. Assuming this to be true, it is intriguing that the majority of companies still have a low percentage of women on their boards. One possibility is that the percentage of women on boards is influenced by national culture.

\section{Gender Diversity and National Culture}

Hofstede (1991) and others (Meyer \& Rowan, 1977) have argued that national culture is reflected in the organizational structure of corporations. Both formal and informal institutional norms represent the shared belief systems that arise from the shared culture of that society. These norms influence the political system, labor market, legal system, and capital market, just to name a few. As such, the composition of the corporate board of directors is likely to reflect the fundamental cultural influences found in that 
society. Therefore, when examining board diversity, it is essential to take both the cultural and political environment into consideration (Sealy et al., 2009).

A number of models have been proposed to describe the cultural differences between countries (Hofstede, 1980; Trompenaars, 1993; House et al., 2004). While no one model can completely capture the complexity of culture, the Hofstede model has the advantage of having been developed using quantitative data drawn from extensive surveys. Consequently, corporate governance research in the area of national culture typically uses the Hofstede model which identifies six dimensions. These dimensions are Power Distance, Individualism vs. Collectivism, Masculinity vs. Femininity, Uncertainty Avoidance, Long-term Orientation, and Indulgence vs. Restraint. In short, power distance refers to the expectation and acceptance of inequality in the distribution of power. The individualism dimension measures the extent to which individuals make decisions for themselves based on what is best for them rather than consensus driven decisions that benefit the group, possibly to the detriment of any individual. Masculine cultures value assertiveness, competitiveness, and material success with distinct traditional gender role expectations. Feminine cultures have less rigid gender roles that both focus on cooperation and harmony. The Uncertainty Avoidance dimension reflects a culture's emotional need for rules and regulations to minimize uncertainty. Long-term orientation suggests a focus on the future rather than the past or present. The final dimension, Indulgence, reflects the extent to which freedom and personal control are encouraged within society. Relationships have been found between these cultural dimensions and organizational behavior (Hofstede et al., 2010; Hickson \& Pugh, 1995).

Humphries and Whelan (2017) demonstrated that a country's corporate governance code is influenced by national culture. Using Hofstede's cultural dimensions, they found that the likelihood that a code includes a recommendation for board gender diversity is influenced by the cultural dimensions of power distance, masculinity, and uncertainty avoidance. It was less likely that the corporate governance codes would mention gender composition in countries with higher scores on these dimensions. On the other hand, there was an increased likelihood that the governance code would make recommendations about gender diversity in countries with higher scores on the individualism dimension.

Others have demonstrated that characteristics of corporate boards are influenced by national culture at the firm level (Li \& Harrison, 2008; Terjesen \& Singh, 2008; Carrasco et al., 2015). Li and Harrison (2008) found that national cultural impacts the composition and leadership structure of corporate boards. The two dependent measures in the study were percentage of outside board directors (board independence) and the presence of consolidated board leadership (CEO as Board Chair). Terjesen and Singh (2008) investigated the role of national environmental factors in relation to the proportion of women on corporate boards. Findings indicated that the percentage of women on boards is likely to be higher in countries with more women in senior management roles and where the gender pay gap is minimal.

Carrasco, et al. (2015) investigated cultural bias with respect to the appointment of women to corporate boards at the firm level. Examination of 7,302 boards from 32 countries indicated that two of Hofstede's cultural dimensions were related to the percentage of women on boards. The percentage of women on boards was found to be lower in high Power Distance countries, as these cultures would have a greater tolerance for inequities in the distribution of power. Similarly, female representation on boards was lower in high Masculinity cultures, as gender roles are very pronounced and deviations are rarely tolerated. These results are consistent with the country-level study conducted by Humphries and Whelan (2017)

This study investigates the relationship between national culture and the gender diversity of corporate boards by examining multinational companies that are only listed on stock exchanges that have no requirement for gender diversity of boards. This provides a control for the regulatory requirement of gender quotas or targets for corporate boards of publicly listed companies, thereby allowing a focus on the national culture rather than blind adherence to regulation. This study extends the prior research through the inclusion of Long-term Orientation and Indulgence, the two newest of Hofstede's (2010) cultural dimensions. 


\section{HYPOTHESIS DEVELOPMENT}

The six Hofstede national cultural dimensions - Power Distance, Individualism-Collectivism, Masculinity-Femininity, Uncertainty Avoidance, Long-term Orientation, and Indulgence-Restraint, are used to examine the impact of national culture on the gender composition of corporate boards.

\section{Power Distance (PDI)}

Power Distance is defined as "the extent to which the less powerful members of institutions and organizations within a country expect and accept that power is distributed unequally" (Hofstede, 1980). In high power distance cultures, traditional gender roles are emphasized with the belief that everyone knows their place and is in their place. This suggests that gender diversity on boards would not be a priority and thus female representation on boards would remain at traditionally low levels. Carrasco et al. (2015) found that in high PDI countries the proportion of women on corporate boards was lower, possibly due to the lack of regulatory requirements. This was further supported by Humphries and Whelan (2017) who found that countries with high PDI scores were less likely to have corporate governance codes that made a recommendation relating to gender composition of the board. Thus, it is expected that the percentage of women on boards will be lower in countries with higher Power Distance scores.

\section{Hypothesis 1: The higher the PDI score, the lower the percentage of women on the board.}

\section{Individualism-Collectivism (IDV)}

The Individualism-Collectivism dimension focuses on the degree of interdependence a society maintains among its members (Hofstede, 1980). In an individualistic society, the links between individuals are weak and need driven. In collective societies, lifelong relationships are desired and maintained within in-groups where loyalty is exchanged for benefits associated with group membership. Consensus of thought and traditional values are common in collective cultures. Within a business environment, "society" can be taken to mean the stakeholders of the company. Stakeholders are those who can affect or are affected by the achievement of the organization's objectives (Freeman, 1984). In individualistic cultures, it is important for the company to assure stakeholders that the board of directors is adequately addressing their individual concerns and needs. A board may appear more legitimate to the stakeholders if there is greater diversity among its members, thereby representing a broader range of viewpoints. Consequently, it is expected that in cultures with higher Individualism scores there will be a higher percentage of women on boards.

\section{Hypothesis 2: The higher the IDV score, the higher the percentage of women on the board.}

\section{Masculinity-Femininity (MAS)}

Hofstede's cultural dimension of Masculinity-Femininity focuses on people's motivation for behavior. For example, the desire to be the best is a commonly expressed goal in High Masculinity cultures; whereas liking what you do is more common in Low Masculinity/High Femininity cultures (Hofstede, 1980). In a more masculine society, it is likely that this translates as a focus on competitiveness, success, and managerial decisiveness in the business world. With societal norms driving gender roles, it is less likely that gender diversity of boards would be prevalent in highly masculine cultures (Sealy et al., 2009). A negative relationship between Masculinity and the percentage of women on boards was found by Carrasco et al. (2015). Therefore, it is expected that the percentage of women on boards will be lower in countries with higher Masculinity scores.

Hypothesis 3: The higher the MAS score, the lower the percentage of women on the board. 


\section{Uncertainty Avoidance (UAI)}

The cultural dimension of Uncertainty Avoidance measures the extent to which the members of a culture feel threatened by ambiguity or the unknown and have created beliefs, rules, and institutions that attempt to minimize these feelings (Hofstede, 1980). This can manifest within a company through the use of rules and policies that reduce ambiguity and improve predictability in order to manage uncertainty. Enhanced predictability through similarity of thought may result in lower acceptance of board diversity. In particular, gender diversity may not be encouraged in high uncertainty avoidance cultures, as female board members may be considered an "unknown" due to historically low numbers of women serving on boards. As such, the percentage of women on boards is likely to be lower in countries with higher Uncertainty Avoidance scores.

Hypothesis 4: The higher the UAI score, the lower the percentage of women on the board.

\section{Long-Term Orientation (LTO)}

The Long-term Orientation dimension may influence the length of time horizon that is the focus of operational and strategic plans of a company. Higher scores on the long-term orientation dimension suggests emphasis on future rewards while lower scores indicate a focus on the past and present (Hofstede et al., 2010). Past research has shown a link between the presence of women on corporate boards and corporate behavior with an implied long-term focus such as higher levels of corporate sustainability reporting and corporate social responsibility (Bernadi \& Threadgill, 2010; Fernandez-Feijoo et al., 2014). Similarly, gender diversity of boards has been identified as advantageous in societies in which sensitivity is necessary for long-term survival (Singh et al., 2006). Therefore, the percentage of women on boards is likely to be higher in countries with higher Long-term Orientation scores.

\section{Hypothesis 5: The higher the LTO score, the higher the percentage of women on the board.}

\section{Indulgence (IVR)}

The Indulgence versus Restraint dimension reflects the extent to which a society is free to fulfil its desires in contrast to controlling impulses through strict societal norms (Hofstede et al., 2010). In a restrained culture, employees or board members may be somewhat reticent about becoming involved in discussions and decision making. In cultures with high Indulgence scores, there is greater freedom of expression which may be reflected in a business context by more willingness of employees to share opinions and engage in debate. This general broadmindedness may manifest at the board level in greater acceptance of female directors in higher Indulgence cultures.

\section{Hypothesis 6: The higher the IVR score, the higher the percentage of women on the board.}

\section{METHODOLOGY}

\section{Sample}

The stock exchange and/or regulatory body in many countries have imposed gender quotas or targets for corporate boards of publicly listed companies. Such requirements make it difficult to study the direct impact of national culture on corporate boards as it may be the regulation rather than the culture that has influenced the number of female directors. To address this concern, the sample used in this study consists of all companies identified by the New York Stock Exchange (NYSE) or the London Stock Exchange (LSE) as international listings as at July 1, 2017. Companies were excluded from the sample if they were also listed on an exchange in their home country.

As neither the NYSE nor the LSE currently impose a gender diversity requirement for the boards of listed companies, it is anticipated that the board diversity of these companies will be influenced by the country of operation rather than the regulatory requirements of the respective stock exchange. This unique approach to sample selection effectively controls for the presence of regulations relating to female 
representation on corporate boards. Prior studies have controlled for this influence through the use of a dichotomous variable which distinguishes between countries with a corporate governance code that specifically refers to the promotion of gender diversity versus countries with a code in which no reference is made to gender diversity (Carrasco et al., 2015). There is the potential for this method to confound the motivation for gender diversity thereby weakening the findings. The final sample includes 175 companies from 35 countries as presented in Table 1 .

\section{TABLE 1 COUNTRY LIST}

\begin{tabular}{lllllll}
\hline Argentina & Columbia & France & Ireland & Malaysia & Peru & Spain \\
Australia & Denmark & Germany & Israel & Netherlands & Russia & Switzerland \\
Belgium & Chile & Greece & Italy & Nigeria & Singapore & Thailand \\
Brazil & China & Hong Kong & Jordan & Norway & South Africa & Turkey \\
Canada & Egypt & India & Luxembourg & Panama & South Korea & Ukraine \\
\hline
\end{tabular}

Model and Variables

\section{Cultural Dimensions}

Scores for the cultural dimensions were collected by hand from the Geert Hofstede Centre website (www.geert-hofstede.com) for the 35 countries identified in Table 1. The dimensions used in this study are Power Distance (PDI), Individualism-Collectivism (IDV), Masculinity-Femininity (MAS), and Uncertainty Avoidance (UAI), Long-term Orientation (LTO), and Indulgence-Restraint (IVR). In general, scores on these dimensions are measured on a scale from zero to one hundred with fifty as the midlevel. A score under fifty can be interpreted as relatively low on that scale and a score over fifty as relatively high. It should be noted that the country scores on the dimensions are relative and should only be used for comparative purposes.

\section{Board Attributes}

Data for the three corporate governance variables were hand collected from the corporate website or the 2018 annual report for each company. Two of the corporate governance variables, Board Size and Chairwoman, are used as control variables in the regression equations. Prior research has shown that the percentage of women on boards is likely to be higher with a larger board and when the board chair is a woman (Carter et al., 2003; Erhardt et al., 2003; Bilimoria, 2006; Carrasco et al., 2015).

Board size (SIZE) is simply the number of board members. Chairwoman (FEMCH) is a dummy variable used to indicate the presence of a female chair of the board. The value is one if the board chair is female and zero otherwise. The third governance variable is the Percentage of Women on Board (PWOB) and is calculated as the number of female board members divided by the total number of board members, multiplied by one hundred. In other words, if the percentage of women on the board is $25 \%$, the number used in the regression analysis would be 25 .

\section{Model}

It is hypothesized that the percentage of women on the board is a function of board size, presence of a female chair, and the scores on the six Hofstede cultural dimensions. An empirical representation of the model is presented in equation (1).

$$
\mathrm{PWOB}_{\mathrm{i}}=\alpha_{0}+\alpha_{1} \mathrm{PDI}_{\mathrm{j}}+\alpha_{2} \mathrm{IDV}_{\mathrm{j}}+\alpha_{3} \mathrm{MAS}_{\mathrm{j}}+\alpha_{4} \mathrm{UAI}_{\mathrm{j}}+\alpha_{5} \mathrm{LTO}_{\mathrm{j}}+\alpha_{6} \mathrm{IVR}_{\mathrm{j}}+\alpha_{7} \mathrm{SIZE}_{\mathrm{i}}+\alpha_{8} \mathrm{FEMCH}_{\mathrm{i}}+\varepsilon
$$

where $\mathrm{PWOB}_{\mathrm{i}}=$ Percentage of Women on Board for firm $\mathrm{i}$

$\mathrm{PDI}_{\mathrm{j}}=$ Score on Power Distance dimension for country $\mathrm{j}$

$\mathrm{IDV}_{\mathrm{j}}=$ Score on Individualism dimension for country $\mathrm{j}$

$\mathrm{MAS}_{\mathrm{j}}=$ Score on Masculinity dimension for country $\mathrm{j}$ 


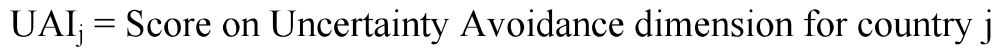

$\mathrm{LTO}_{\mathrm{j}}=$ Score on Long-term Orientation dimension for country $\mathrm{j}$

$\mathrm{IVR}_{\mathrm{j}}=$ Score on Indulgence dimension for country $\mathrm{j}$

$\mathrm{SIZE}_{\mathrm{i}}=$ Number of Board Members for firm

$\mathrm{FEMCH}_{\mathrm{i}}=$ Female Chair of Board for firm i $(\mathrm{FEMCH}=1$ if board chair is female $/ 0$ otherwise $)$

$\varepsilon=$ error term

$\mathrm{j}=$ country in which firm $\mathrm{i}$ is headquartered and/or primarily operates

The impact on the percentage of women on the board for each variable is represented by the coefficients $\alpha_{1}$ through $\alpha_{8}$. The expected sign of each coefficient is presented in Table 2. Ordinary Least Squares (OLS) regression is used to estimate the models presented in this study. Seven versions of the model are estimated. The first model includes the two control variables and all six of the cultural dimension variables. Models 2 through 7 include the two control variables and one each of the cultural dimension variables. A similar model and analysis was used in Carrasco et al. (2015). This study adopted the same approach to facilitate the comparison of results.

TABLE 2

EXPECTED RELATIONSHIPS

\begin{tabular}{|c|c|c|c|}
\hline Coefficient & Variable & Expected Sign & Hypothesis \\
\hline$\alpha_{1}$ & PDI & - & $\mathrm{H} 1$ \\
\hline$\alpha_{2}$ & IDV & + & $\mathrm{H} 2$ \\
\hline$\alpha_{3}$ & MAS & - & $\mathrm{H} 3$ \\
\hline$\alpha_{4}$ & UAI & - & $\mathrm{H} 4$ \\
\hline$\alpha_{5}$ & LTO & + & $\mathrm{H} 5$ \\
\hline$\alpha_{6}$ & IVR & + & $\mathrm{H} 6$ \\
\hline$\alpha_{7}$ & SIZE & + & Control variable \\
\hline$\alpha_{8}$ & FEMCH & + & Control variable \\
\hline
\end{tabular}

\section{RESULTS AND DISCUSSION}

\section{Descriptive Analysis and Correlation Analysis}

Table 3 provides basic descriptive statistics for all the variables used in the study. Board size ranged from 3 to 20 with an average of 7.98 directors of which only $11.6 \%$ are women. This percentage is slightly higher than that found in past research and may be indicative of a general trend of increasing gender diversity on boards. However, it is still a very low percentage that indicates poor representation of women on boards. The variation in the cultural dimension scores indicates sufficient differences among the countries to support their use in the regression analyses. 
TABLE 3

DESCRIPTIVE STATISTICS

\begin{tabular}{|l|c|c|c|c|}
\hline & Minimum & Maximum & Mean & Std. Dev. \\
\hline Board Composition ( $\mathrm{n}=175$ companies) & & & & \\
\hline Percentage of women on board & 0 & 45.46 & 11.62 & 12.44 \\
\hline Board size & 3 & 20 & 7.98 & 2.69 \\
\hline Number of female directors & 0 & 7 & 0.99 & 1.17 \\
\hline Cultural Dimension ( $\mathrm{n}=35$ countries) & & & & \\
\hline PDI & 13 & 100 & 58.9 & 21.8 \\
\hline IDV & 11 & 90 & 45.6 & 23.7 \\
\hline MAS & 8 & 70 & 47.8 & 15.7 \\
\hline UAI & 8 & 100 & 65.5 & 23.9 \\
\hline LTO & 7 & 100 & 48.0 & 25.0 \\
\hline IVR & 4 & 84 & 497 & 19.4 \\
\hline
\end{tabular}

Tables 4 and 5 present correlation coefficients for the control variables and culture variables. The Percentage of Women on Board is significantly positively correlated with Board Size, Chairwomen, and the cultural dimension of Individualism. A significant negative correlation was found between the Percentage of Women on Board the cultural dimension of Power Distance. These findings are consistent with the hypotheses presented.

TABLE 4

\section{CORRELATION COEFFICIENTS - DEPENDENT AND INDEPENDENT VARIABLES}

\begin{tabular}{lc}
\hline & PWOB \\
\hline Control Variables & $0.183^{*}$ \\
Board Size & $0.311^{* *}$ \\
Chairwomen & \\
Cultural Dimension Variables & $-0.150^{*}$ \\
PDI & $0.166^{*}$ \\
IDV & 0.123 \\
MAS & -0.032 \\
UAI & 0.006 \\
LTO & 0.080 \\
IVR & Correlation is significant at the 0.01 level (2-tailed) \\
$*$ Correlation is significant at the 0.05 level (2-tailed) \\
\hline
\end{tabular}

The Indulgence dimension is negatively correlated with Power Distance and Long-term Orientation. A weaker but positive correlation exists between Indulgence and Individualism. The strongest correlation is a negative association between Power Distance and Individualism. The significant correlations between these culture variables present concerns with multicollinearity. To ensure the regression coefficients can be interpreted with some confidence, variance inflation factors (VIF) are calculated for the variables in each regression model. The average VIF for the models range from 1.03 to 2.81 indicating low multicollinearity. 
TABLE 5

CORRELATION COEFFICIENTS - NATIONAL CULTURE VARIABLES

\begin{tabular}{lcccccc}
\hline & PDI & IDV & MAS & UAI & LTO & IVR \\
\hline PDI & 1.000 & & & & & \\
IDV & $-0.635^{* *}$ & 1.000 & & & & \\
MAS & -0.097 & 0.172 & 1.000 & & & \\
UAI & 0.169 & -0.201 & 0.291 & 1.000 & & \\
LTO & 0.113 & 0.089 & -0.027 & 0.088 & 1.000 & \\
IVR & $-0.465^{* *}$ & $0.351^{*}$ & 0.150 & -0.218 & $-0.456^{* *}$ & 1.000 \\
\hline ** Correlation is significant at the 0.01 level (2-tailed) & & \\
$*$ Correlation is significant at the 0.05 level (2-tailed) & & \\
\hline
\end{tabular}

\section{Tests of Hypotheses}

The results of the regression analysis indicate that national culture influences the percentage of women on boards. The significance of the results varies by cultural dimension and the model used in the regression. Table 6 provides a summary of the results of the multivariate OLS regression models used to test the hypotheses while controlling for board size and the presence of a female board chair.

Model 1 includes all the cultural dimension variables and the control variables. The regression analysis using this model provides support for Hypotheses 2 and 5. The percentage of women on boards is greater in cultures with higher Individualism and Long-term Orientation scores. As expected, there is a significant positive relationship between the percentage of women on boards and the board size and the presence of a female board chair. The adjusted R-square indicates that $17.4 \%$ of the variation in the percentage of women on boards can be explained by these variables. This model has the highest adjusted $\mathrm{R}$-square of all the models presented.

TABLE 6

REGRESSION ANALYSIS

\begin{tabular}{|c|c|c|c|c|c|c|c|c|}
\hline Variable & $\begin{array}{l}\text { Exp. } \\
\text { Sign }\end{array}$ & $\begin{array}{c}\text { Model } 1 \\
\text { All }\end{array}$ & $\begin{array}{c}\text { Model } 2 \\
\text { PDI }\end{array}$ & $\begin{array}{c}\text { Model } 3 \\
\text { IDV }\end{array}$ & $\begin{array}{c}\text { Model } 4 \\
\text { MAS }\end{array}$ & $\begin{array}{c}\text { Model } 5 \\
\text { UAI }\end{array}$ & $\begin{array}{c}\text { Model } 6 \\
\text { LTO }\end{array}$ & $\begin{array}{c}\text { Model } 7 \\
\text { IVR }\end{array}$ \\
\hline Intercept & & $\begin{array}{l}-7.913 \\
(-0.63)\end{array}$ & $\begin{array}{c}8.139 \\
(2.25)^{* *}\end{array}$ & $\begin{array}{l}-0.675 \\
(-0.22)\end{array}$ & $\begin{array}{l}0.673 \\
(0.17)\end{array}$ & $\begin{array}{l}2.400 \\
(0.71)\end{array}$ & $\begin{array}{l}1.830 \\
(0.48)\end{array}$ & $\begin{array}{l}-0.379 \\
(-0.11)\end{array}$ \\
\hline PDI & - & $\begin{array}{l}-0.074 \\
(-0.73)\end{array}$ & $\begin{array}{c}-0.089 \\
(-2.37)^{* * *}\end{array}$ & & & & & \\
\hline IDV & + & $\begin{array}{c}0.101 \\
(1.30)^{*}\end{array}$ & & $\begin{array}{c}0.087 \\
(2.43)^{* * *}\end{array}$ & & & & \\
\hline MAS & - & $\begin{array}{l}0.088 \\
(1.30)\end{array}$ & & & $\begin{array}{l}0.041 \\
(0.49)\end{array}$ & & & \\
\hline UAI & - & $\begin{array}{l}0.027 \\
(0.61)\end{array}$ & & & & $\begin{array}{l}0.003 \\
(0.71)\end{array}$ & & \\
\hline LTO & + & $\begin{array}{c}0.088 \\
(1.59)^{*}\end{array}$ & & & & & $\begin{array}{l}0.005 \\
(0.15)\end{array}$ & \\
\hline IVR & + & $\begin{array}{c}-0.020 \\
(-0.198)\end{array}$ & & & & & & $\begin{array}{l}0.050 \\
(1.05)\end{array}$ \\
\hline Board size & + & $\begin{array}{c}0.976 \\
(2.70)^{* * *}\end{array}$ & $\begin{array}{c}0.956 \\
(2.92)^{* * *}\end{array}$ & $\begin{array}{c}0.915 \\
(2.78)^{* * *}\end{array}$ & $\begin{array}{c}1.002 \\
(2.99)^{* * *}\end{array}$ & $\begin{array}{c}1.046 \\
(3.17)^{* * *}\end{array}$ & $\begin{array}{c}1.112 \\
(3.27)^{* * *}\end{array}$ & $\begin{array}{c}1.098 \\
(3.17)^{* * *}\end{array}$ \\
\hline Chairwoman & + & $\begin{array}{c}25.692 \\
(4.78)^{* * *}\end{array}$ & $\begin{array}{c}26.616 \\
(5.07)^{* * *}\end{array}$ & $\begin{array}{c}26.485 \\
(5.06)^{* * *}\end{array}$ & $\begin{array}{c}24.791 \\
(4.64)^{* * *}\end{array}$ & $\begin{array}{c}25.326 \\
(4.73)^{* * *}\end{array}$ & $\begin{array}{c}25.175 \\
(4.71)^{* * *}\end{array}$ & $\begin{array}{c}26.236 \\
(4.86)^{* * *}\end{array}$ \\
\hline $\operatorname{Adj} . R^{2}$ & & $17.4 \%$ & $15.9 \%$ & $16.1 \%$ & $13.4 \%$ & $13.2 \%$ & $13.6 \%$ & $15.2 \%$ \\
\hline F-test & & 5.25 & 11.99 & 12.11 & 9.99 & 9.80 & 10.06 & 10.64 \\
\hline Mean VIF & & 2.81 & 1.03 & 1.04 & 1.05 & 1.03 & 1.05 & 1.05 \\
\hline
\end{tabular}


Models 2 through 7 include only one each of the cultural dimensions in addition to the control variables. After controlling for board size and the presence of a female board chair, the regression results indicate that the percentage of women on boards is negatively related to Power Distance and positively related to Individualism. No significant relationships were found for the other cultural dimensions. It is interesting to note that the Power Distance dimension was not significant in the model that included all the cultural dimension but had strong significance when considered alone. Each of the models with significant independent variables have an adjusted R-square of around $16 \%$.

Model 2 provides support for Hypothesis 1; the higher the PDI score, the lower the percentage of women on the board. The coefficient on the IDV variable of -0.089 suggests that a 10 point increase in the PDI score may result in a $0.89 \%$ decrease in the percentage of women on the board. Countries with high Power Distance scores tend to accept unequal distribution of power in its organizations. It can be argued that in such cultures, women may not have the social capital to earn a place on a corporate board. Consequently, the lack of female representation on corporate boards in high Power Distance cultures may be due to a tolerance of traditional male dominance in business settings.

Hypothesis 2 is further supported by Model 3; the higher the IDV score, the higher the percentage of women on the board. The coefficient on the IDV variable of 0.087 suggests that a 10 point increase in the IDV score may result in a $0.87 \%$ increase in the percentage of women on the board. Individualism implies a commitment to the rights of the individual and therefore representation for all. As such, in high Individualism cultures, a board may appear to be more legitimate if it represents the interests of a broader range of individuals which could be achieved through greater female representation on the board.

The coefficients for PDI and IDV are similar in magnitude in their respective models, indicating they have a similar impact on the percentage of women on boards, albeit in opposite directions. These results both support and contradict the result presented by Carrasco et al. (2015) which showed that PDI and MAS were inversely related to the PWOB. The coefficient for PDI in both studies is similar in magnitude and indicates a negative relationship with the percentage of women on boards. However, unlike Carrasco et al. (2015), this study finds no significant relationship between MAS and PWOB. Instead, this study finds a significant positive relationship between IDV and PWOB. The inclusion of the LTO dimension extends the prior research and provides further evidence that the gender diversity of corporate boards may be influenced by national culture. Long-term Orientation suggests a focus on the future of the company and its stakeholders rather than dwelling in the past. In high Long-term Orientation cultures, the presence of female directors may encourage the board to consider the longer-term consequences of its actions. For example, this may be reflected in an emphasis on corporate social responsibility.

One concern with the sample involves the small number of companies that have a female CEO; only 5 out of the sample of 175 . The analyses were replicated without these five companies in the sample and the regression results are consistent with the initial outcomes.

\section{CONCLUSION}

This study investigates the relationship between national culture and the gender diversity of corporate boards by examining the percentage of women on boards for international companies listed on the New York or London Stock Exchanges. Hofstede's (2010) cultural dimensions are used to measure national culture. After controlling for board size and the presence of a female board chair, the percentage of women on boards was found to be higher in countries with high Individualism and Long-term Orientation scores and lower in countries with high Power Distance scores. No significant relationships were found for Masculinity, Uncertainty Avoidance, and Indulgence. This contrasts with prior research (Carrasco et al., 2015) in which a negative relationship was found between Masculinity and the percentage of women on boards and no relationship was found for Individualism. It should be noted that this is the first study to examine the relationship with respect to Long-term Orientation.

The limitations of this study primarily relate to the assumptions about the sample and the sample size itself. The companies included in the sample are considered international listings on the New York Stock Exchange or the London Stock Exchange. Companies were excluded from the sample if they were also 
listed on an exchange in their home country. The assumption was that the companies in the sample would be influenced by the national culture in their home countries but not bound by their corporate governance codes. However, some of these companies may be planning to list on their home exchanges and may therefore be modifying their board of directors to meet specific gender diversity requirements that they may be required to adhere to in the future. Another point to consider is that multinational companies may be less impacted by the national culture of their home country than a domestic company in that country due to their experiences with global operations. The sample size was limited by the number of international companies listed on the NYSE and LSE. Further research would benefit from the examination of a broader range of countries.

The results of this study highlight the importance of understanding cultural influences on board diversity. If board efficiency and firm performance are enhanced with greater female representation on the board, then firms should consider increasing diversity voluntarily rather than waiting for a mandate from regulators. The findings suggest that this may be more acceptable to stakeholders in cultures with lower Power Distance and higher Individualism or Long-term Orientation. In countries with strong cultural resistance to gender diversity on corporate boards, forcing the appointment of women may actually result in weaker firm performance. The reaction to the presence of female directors may illicit hostility and conflict on the board, possibly limiting its effectiveness. Additionally, female directors may be viewed as a token gesture with little attention paid to any comments made, especially those of a nontraditional nature. Future research should examine the moderating effect of national culture on the relationship between gender diversity of corporate boards on firm performance.

\section{REFERENCES}

Bernadi, R.A., \& Threadgill V.H. (2010). Women directors and corporate social responsibility. Electronic Journal of Business Ethics and Organizational Studies, 15(2), 15-21.

Bilimoria, D. (2006). The Relationship Between Women Corporate Directors and Women Corporate Officers. Journal of Managerial Issues, 18(1), 47-61.

Carrasco, A., Francoeur, C., Labell, R., Laffarga, J., \& Ruiz-Barbadillo, E. (2015). Appointing Women to Boards: Is There a Cultural Bias? Journal of Business Ethics, 129(2), 429-444.

Carter, D.A., Simkins, B.J., \& Simpson, W.G. (2003). Corporate Governance, Board Diversity, and Firm Value. The Financial Review, 38, 33-53.

Erhardt, N.L., Werbel, J.D., \& Shrader, C.B. (2003). Board of Director Diversity and Firm Financial Performance. Corporate Governance, 11(2), 102-111.

Fernandez-Feijoo, B., Romero, S., \& Ruiz-Blanco, S. (2014). Women on Boards: Do They Affect Sustainability Reporting. Corporate Social Responsibility and Environmental Management, 21, 351-364.

Freeman, R.E. (1984). Strategic management: A stakeholder approach. Cambridge: Cambridge University Press.

Geiger, S.W., \& Marlin, D. (2016). The Impact of Board Size and Female Board Representation on Firm Financial Performance. Leadership \& Organizational Management Journal, (4), 37-49.

Hermalin, B.E., \& Weisbach, M.S. (1991). The Effects of Board Composition and Direct Incentives on Firm Performance. Financial Management, 20(4), 101-112.

Hickson, D.J., \& Pugh, D.S. (1995). Management Worldwide: The Impact of Societal Culture on Organizations Around the Globe. London: Penguin.

Hofstede, G. (1980). Culture's Consequences: International Differences in Work-related Values. Newbury Park: Sage.

Hofstede, G. (1991). Culture and Organizations: Software of the Mind. London: McGraw-Hill.

Hofstede, G. H., Hofstede, G. J., \& Minkov, M. (2010). Cultures and organizations: Software of the mind; intercultural cooperation and its importance for survival (3rd ed). New York: McGrawHill. 
House, R.J., Hanges, P.G., Javidan, H., Dorfman, P.W., \& Gupta, V. (2004). Culture, leadership, and organizations across nations. London: Sage Publications.

Humphries, S.A., \& Whelan, C. (2017). National culture and corporate governance codes. Corporate Governance: The International Journal of Business in Society, 17(1), 152-163.

Jensen, M.C. (1993). The Modern Industrial Revolution, Exit, and the Failure of Internal Control Systems. The Journal of Finance, 48(3), 831-877.

Li, J., \& Harrison, J. (2008). Corporate governance and national culture: A multi-country study. Corporate Governance, 8(5), 607-621.

Low, D.C.M., Roberts, H., \& Whiting, R.H. (2015). Board gender diversity and firm performance: Empirical evidence from Hong Kong, South Korea, Malaysia and Singapore. Behavioral Finance and Recent Developments in Capital Markets, Pacific-Basin Finance Journal, 35, 381-401.

Meyer, J.W., \& Rowan, B. (1977). Institutionalized organizations: Formal structure as myth and ceremony. American Journal of Sociology, 83(2), 340-363.

Sabatier, M. (2015). A women's boom in the boardroom: effects on performance? Applied Economics, 47(26), 2717-2727.

Sanan, N.K. (2016). Board Gender Diversity and Firm Performance: Evidence from India. Asian Journal of Business Ethics, 5(1-2), 1-18.

Sealy, R., Dolder, E., \& Vinnicombe, S. (2009). Increasing diversity on public and private boards. UK Government Equalities Office.

Sing, V., Vinnicombe S., \& Terjesen, S.A. (2006). Women advancing onto the corporate board. In C. Bilmoria \& S. Piderit (Eds.), Handbook of Women in Business and Management (pp. 304-329). Cheltenham: Edward Elger.

Solakoglu, M.N., \& Demir, N. (2016). The Role of Firm Characteristics on the Relationship Between Gender Diversity and Firm Performance. Management Decision, 54(6), 1407-1419.

Terjesen, S., \& Singh, V. (2008). Female presence on corporate boards: A multi-country study of environmental context. Journal of Business Ethics, 83(1), 55-63.

Terjesen, S., Couto, E., \& Francisco, P. (2016). Does the presence of independent and female directors impact firm performance? A multi-country study of board diversity. Journal of Management \& Governance, 20(3), 447-483.

Tinsley, C.H., Wade, J.B., Main, B.G.M., \& O’Reilly, C.A. (2017). Gender Diversity on U.S. Corporate Boards: Are we running in place? ILR Review, 70(1), 160-189.

Trompenaars, F. (1993). Riding the waves of culture: Understanding cultural diversity in business. London: Nicholas Brearly. 